J. Clin. Chem. Clin. Biochem.

Vol. 20, 1982, pp. 157-161

\title{
Interlaboratory Comparison of Radioimmunological Calcitonin Determination ${ }^{1}$ )
}

\author{
Presented for the European PTH ${ }^{2}$ ) Study Group (EPSG) \\ by $F$. Raue
}

\section{Abt. Innere Medizin VI - Endokrinologie, Universität Heidelberg}

(Received July 13/November 17, 1981)

Participating laboratories of the EPSG:

R. Ardaillou, Hopital Tenon, Paris (France)

H. Brauman and J. Corvilain, Hopital Univ. Brugmann, Bruxelles (Belgium)

P. Burckhardt, Clin. Med. Univ. Lausanne (Switzerland)

J. A. Fischer and M. A. Dambacher, Orthopäd. Univ.-Klinik und Department für Innere Medizin, Zürich (Switzerland)

W. Hackeng, Bergwegziekenhuis, Rotterdam (Netherlands)

E. Keck, Med. Univ. Klinik Düsseldorf (Germany)

E. Leicht and G. Biro, Med. Univ. Klinik Homburg-Saar (Germany)

$H$. Rapado and P. Esbrit, Clin. Nuestra Sen. La Conception, Madrid (Spain)

H. Schmidt-Gayk, Med. Univ. Klinik, Heidelberg (Germany)

$P$. O. Schwille, Chir. und Urol. Univ. Klinik Erlangen (Germany)

W. G. Wood, Med. Univ. Klinik, Lübeck (Germany)

R. Ziegler and F. Raue, Abt. Endokrinologie, Univ. Klinik Heidelberg (Germany)

Summary: An interlaboratory study for the radioimmunological determination of calcitonin was performed within the European PTH Study Group (ESPG), to improve comparability using external quality control. Twelve laboratories determined calcitonin in 21 deep frozen samples using their respective calcitonin radioimmunoassay systems. The samples included standard curves of human calcitonin (sequence 1-32) in serum as well as in assay buffer, several dilutions of a serum from a patient with medulläry thyroid carcinoma, and additional sera containing calcitonin levels of clinical importance. For evaluation, the known concentrations were related to the measured values of each laboratory, and of all laboratories together. Except for one, the laboratories recognized the different dilutions used, although absolute values were scattered over a wide range. Satisfactory agreement was reached only when the data were calculated as the percentage of a given value. In future, a serum with a well defined and constant calcitonin concentration should be used as an international standard in all determination of calcitonin by radioimmunoassay.

\section{Ringversuch zur radioimmunologischen Calcitoninbestimmung ìm Serum}

Zusammenfassung: In einem von der European PTH Study Group (EPSG) veranstalteten externen Ringversuch nach dem șogenannten „Münchner Modell“" wurde die Vergleichbarkeit der radioimmunologischen Calcitoninbestimmung überprüft. 12 teilnehmende Laboratorien erhielten 21 tiefgefrorene Serumproben mit einer verstecktẻn Standaṛdkurve für humanes Calcitonin (Sequenz 1-32) aufgelöst sowohl in Serum als auch in Puffer, zusätzlich Serumproben von Patienten mit medullärem Schilddrüsencarcinom in verschiedenen Verdünnungen. Mit Ausnahme eines Laboratoriums konnten alle die Verdünnungsschritte in der vorgegebenen Reihenfolge messen, obwohl die Absolutwerte über einen weiten Bereich streuten. Erst nach Umrechnung der Meßergebnisse auf einen gemeinsamen Bezugswert ergab sich eine befriedigende Übereinstimmung. Für die Zukunft könnte eine solche konstante und gut definierte Serumprobe als internationaler Standard im Radioimmunoassay für humanes Calcitonin verwendet werden.

\section{Introduction}

Elevated calcitonin concentrations in serum have been reported in various clinical conditions such as $\mathrm{C}$-cell-

\footnotetext{
1) Supported by SFB 136 -. Krebsforschung - Project E 3

2) Parathyrin
}

carcinoma (medullary thyroid carcinoma) and tumours secreting calcitonin ectopically, in renal insufficiency, or during pregnancy and lactation $(1,2)$. With the majority of published radioimmunoassays pathologically elevated values can be measured with accuracy, while levels in the normal range remain poorly defined. Moreover absolute values vary considerably $(3,4,5)$. 
For a better comparison of various radioimmunoassay systems for calcitonin determination, we performed an international collaborative study within the European PTH Study Group. A similar collaborative study was run previously with parathyrin (6).

The external quality control survey presented here was based on the "Munich Model" (7-9). Twelve laboratories participated in the measurement of 21 samples using their routine calcitonin-radioimmunoassays. We collected the data obtained in these laboratories and related the results to the different methods and reagents used. Since we were able to evaluate results of a relatively large number of samples, some of the sources of error could be pinpointed.

\section{Materials and Methods}

Test sera

Twenty one samples, each as two aliquots (in plastic tubes, Eppendor ${ }^{\circledR}$ reaction vials), were sent frozen in dry ice to each participant. The samples, which were randomly numbered (tab. 1), included a six point standard curve of synthetic human calcitonin (sequence 1-32) (Ciba Geigy) in serum as well in hormone-free buffer and a zero value. The standard curve was a geometric dilution of human calcitonin in concentrations ranging from 0.3 to $9.6 \mu \mathrm{g} / 1$ dissolved in $0.05 \mathrm{~mol} / 1$ barbiturate buffer $\mathrm{pH} 7.6$ containing $50 \mathrm{ml} / 1$ of serum from a thyreoidectomized patient and in pooled serum obtained from five normal subjects with undetectable calcitonin levels. Calcitonin was also undetectable in the serum of the thyreoidectomized patient.

Furthermore five dilution steps were included ranging from $1: 4$ to $1: 64$ of a serum from patient B.F. . with medullary thyroid carcinoma diluted in the pooled normal serum, together with another serum pool of medullary thyroid carcinoma patients with high calcitonin levels.

\section{Collaborating laboratories}

The twelve collaborating laboratories are listed by code numbers to preserve anonymity.

\section{Radioimmunoassay technique}

Technical details of the radioimmunoassays used are listed on table 2. Eight different antisera against human calcitonin were obtained by immunising goats in nine instances and chicken, rabbit or guinea pig in the others. Some laboratories employed different antisera for comparison. Synthetic human calcitonin was radioiodinated with ${ }^{125}$ I or ${ }^{131}$ I using the chloramine $T$ method according to Hunter \& Greenwood (10); specific activities ranged from $2.6-16.7 \mathrm{MBq} / \mu \mathrm{g}$. Some laboratories purified the labelled hormone by gel filtration, others by QUSO extraction (11). as the standard, ten laboratories used synthetic human calcitonin (sequence $1-32$ ) from Ciba Geigy, the other two using products from Armour and Organon,
respectively.

All the laboratories performed preincubations in the absence of labelled hormone between eighteen hours and five days. Total incubation times ranged from twenty five hours to eight days. For separation of the bound from the free hormone ten laboratories used dextran coated charcoal, while two laboratories used polyethyleneglycol. All the laboratories made use of homologous systems with synthetic human calcitonin (sequence 1-32).

\section{Results}

Figures 1a-1b show the results for determination of the two standard curves (samples $1-14$ of tab. 1). In each figure the added concentration is plotted on the horizontal axis, the measured calcitonin concentrations on the vertical axis. The expected correlation between the two sets of corresponding values is defined by a straight line with a slope of $45^{\circ}$. All participating laboratories except for one were able to measure increasing amounts of human calcitonin in the given range of 0.3 to 9.6 $\mu \mathrm{g} / \mathrm{l}$. Calcitonin values measured in buffer (fig. 1b) or serum (fig. 1a) did not differ. In contrast, the absolute values of the calcitonin concentrations differed considerable, e.g. in the sample containing $0.3 \mu \mathrm{g} / 1,0.23$ to $1.55 \mu \mathrm{g} / \mathrm{l}$ were recovered. Moreover dilution curves of the serum from patient B.F. with medullary thyroid carcinoma were scattered over a wïde range (fig. 1c).

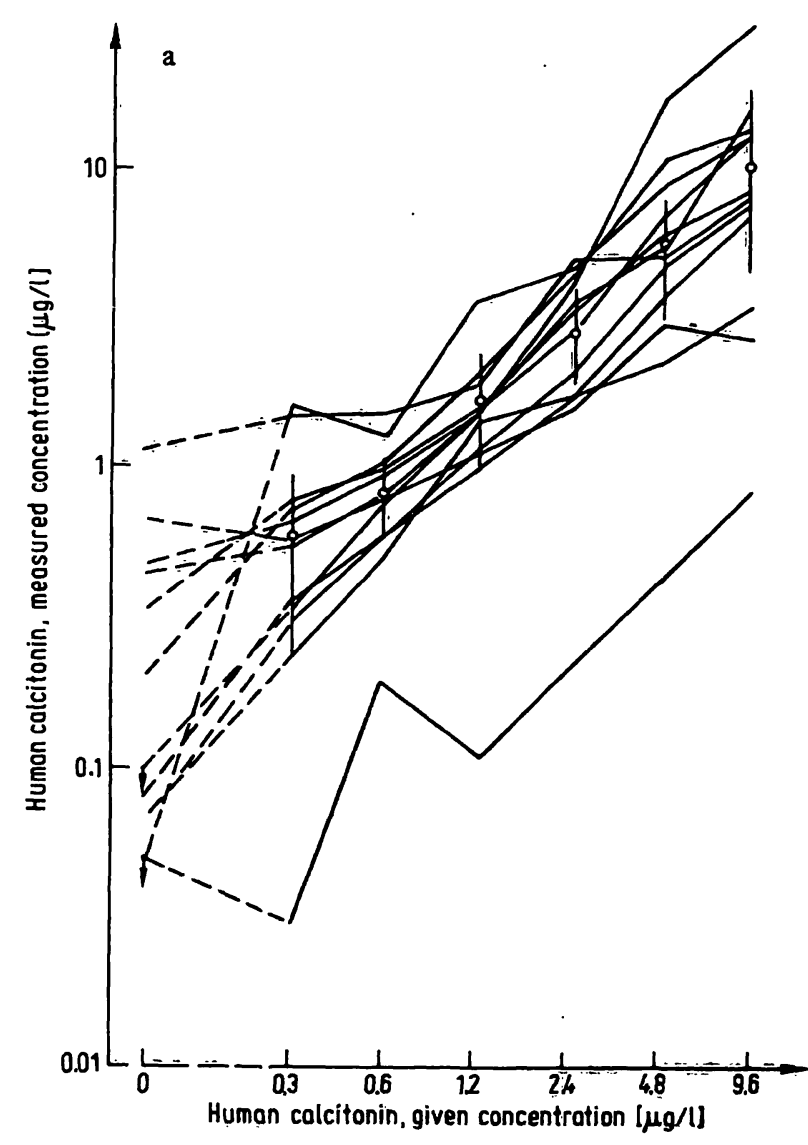

Fig. 1a. Relationships between given and measured concentrations of human calcitoninin; standard dilutions in a $0: 05 \mathrm{~mol} / 1$ barbiturate buffer containing a fraction of serum of $0.05 ; \bar{x} \pm S D$.

1b. Relationship between given and measured concentrâtions of geometric standard dilutions with synthetic human calcitonin diluted in pooled normal serum with undetectable calcitonin; $\overline{\mathbf{x}} \pm$ SD.

1c. Dilution steps and measured values of the serum from patient B.F. with medullary thyroid carcinomia diluted in pooled normal serum with undetectable calcitonin; - $\overline{\mathrm{x}} \pm$ SD.

$$
\text { i }
$$

J. Clin. Chem. Clin. Biochem. / Vol. 20, 1982 / No. 3 


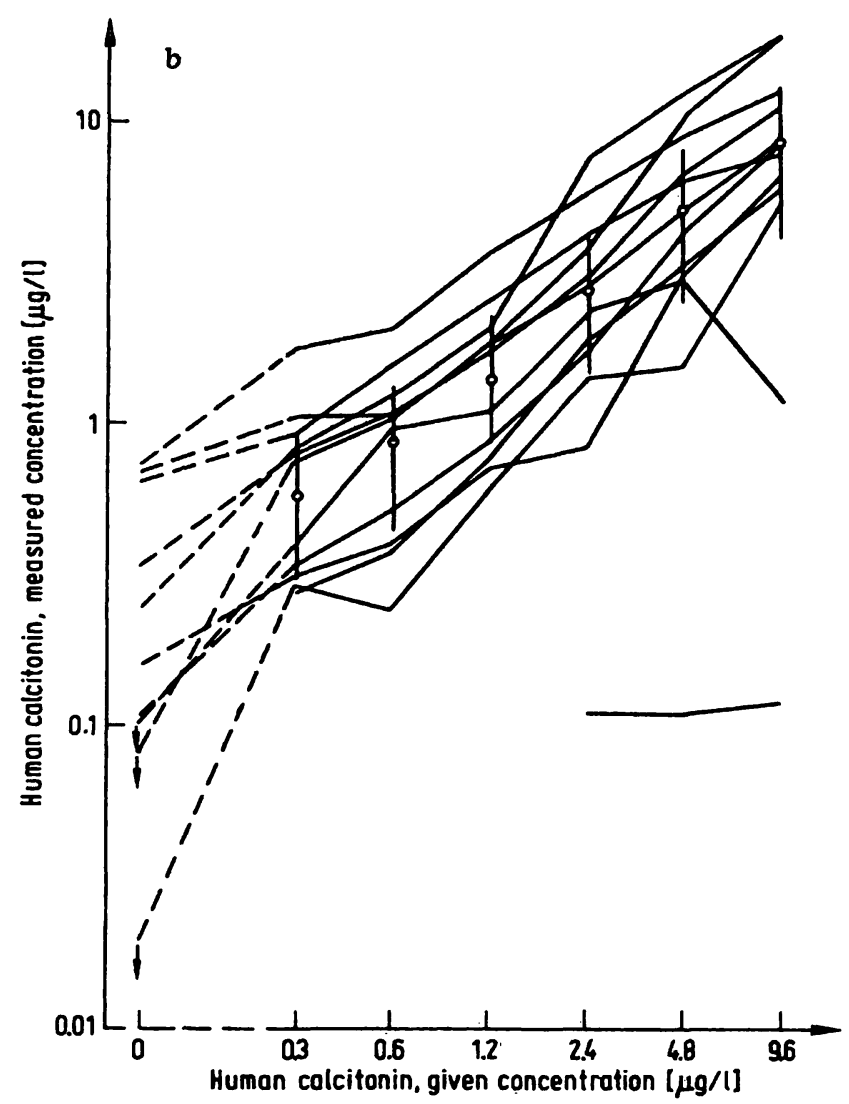

Except for one, all laboratories were able to detect the different dilution steps. From the five dilution steps the following values were calculated for each laboratory: mean concentration in undiluted serum, its standard error and the coefficient of variation. From means of each laboratory the same parameters were calculated for all laboratories (tab. 3). The concentration of the undiluted serum varied between 16.2 and $165.8 \mu \mathrm{g} / \mathrm{l}$, the individual coefficient of variation between 11.5 to $69.3 \%$. The mean value, considering all laboratories except 4,6 and 12 , was $53.3 \pm 25.1(\mathrm{x} \pm \mathrm{SD}) \mu \mathrm{g} / 1$ with a coefficient of variation for all laboratoties (interassay) of $46.9 \%$.

In order to judge the clinical usefulness of human absolute values the concentration in the serum of patient B.F. with medullary thyroid carcinoma diluted 1:64 was referred to as 1 and the values of the four other dilutions were indicated as a factor of this value. The dilution curves expressed as a factor of the first dilution step were closer together (fig. 2) than those in absolute concentrations (fig. 1c).

In order to judge the clinical usefullness of human calcitonin radioimmunoassay we evaluated the ability to differentiate between normal and pathological values using samples 15, 20 and 21 (tab. 1). In figure 3 the reference range of all laboratories is indicated together with the results of three sera. The pooled serum from a patient with medullary thyroid carcinoma was expected to show a very high calcitonin level. The serum from

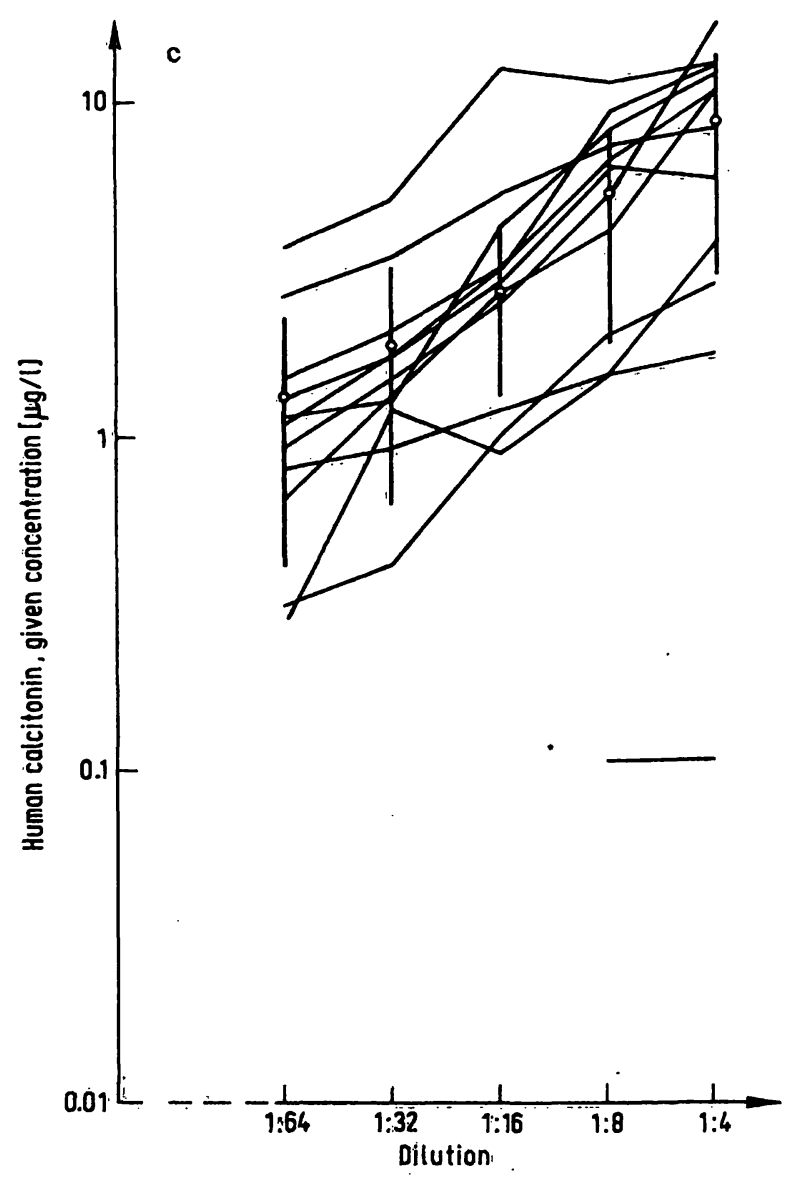
patient B.F. with medullary thyroid carcinoma diluted

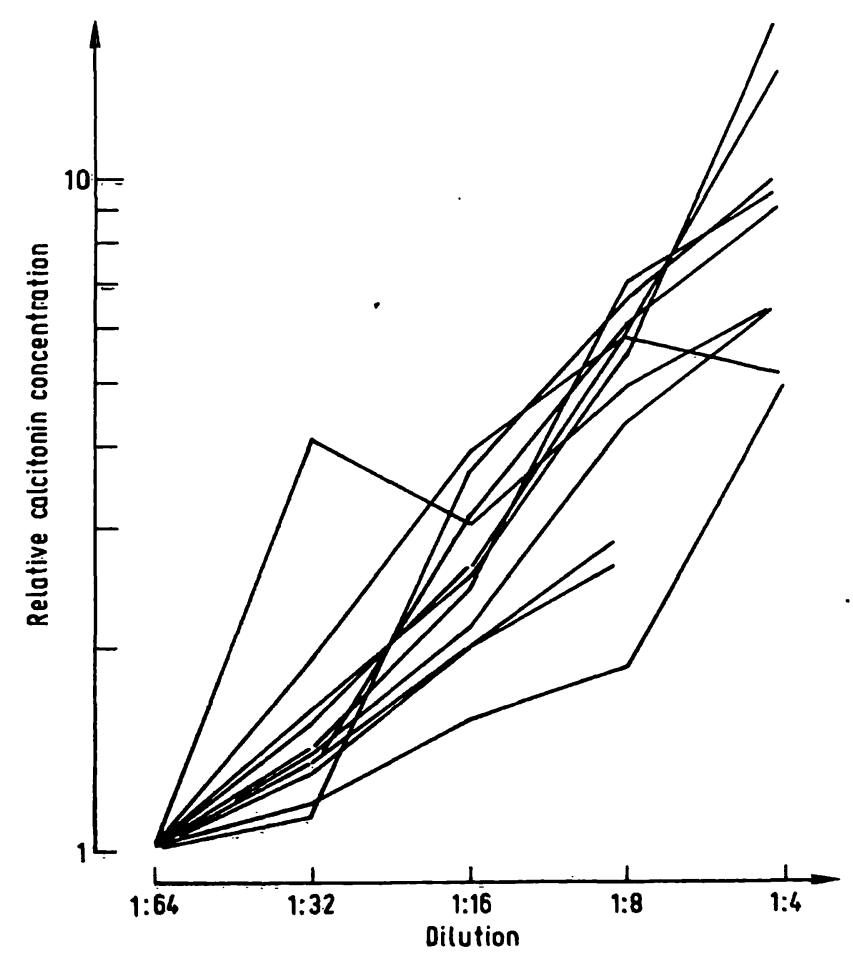

Fig. 2. Dilution curves as in fig. $1 \mathrm{c}$ after recalculation using the $1: 64$ dilution step as 1 . 


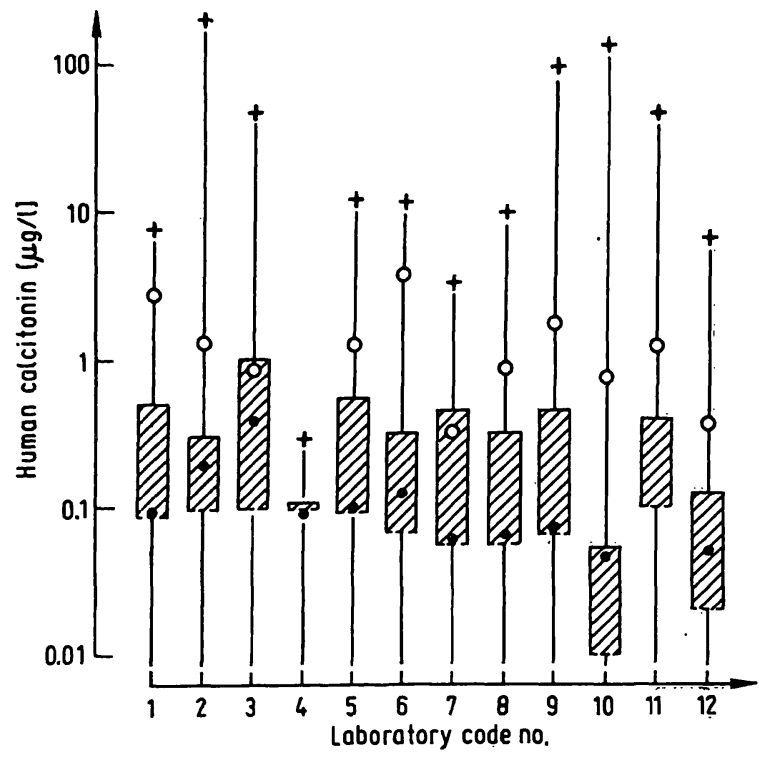

Fig. 3. Comparison of the reference ranges (hatched bars) and three measured values from the twelve laboratories (undetectable calcitonin value $=$ serum of the thyroidectomized patients; medium calcitonin value $=$ serum dilution step 1:64 of the medullary thyroid carcinoma patient B.F $;$ high calcitonin = medullary thyroid carcinoma serum pool).

\begin{tabular}{|c|c|c|c|}
\hline Matrix & $\begin{array}{l}\text { No. } \\
\text { of } \\
\text { sample }\end{array}$ & $\begin{array}{l}\text { Syn= } \\
\text { thetic } \\
\text { human } \\
\text { calcitonin } \\
\text { (sequence } \\
1-32 \text { ) } \\
\text { added } \\
(\mu \bar{g} / \mathrm{l})\end{array}$ & Dilution \\
\hline $\begin{array}{l}\text { Barbiturate buffer, } 0.05 \mathrm{~mol} / 1 \text {, } \\
\text { pH } 7.6 \text { containing } 50 \mathrm{ml} / 1 \text { of } \\
\text { serum of a thy yroidectomized } \\
\text { patient (diluent) }\end{array}$ & $\begin{array}{l}1 \\
2 \\
3 \\
4 \\
5 \\
6 \\
7\end{array}$ & $\begin{array}{l}0 \\
0.3 \\
0.6 \\
1.2 \\
2.4 \\
4.8 \\
9.6\end{array}$ & \\
\hline $\begin{array}{l}\text { Serum pooled from } 5 \text { noimal } \\
\text { volunteers with undetectable } \\
\text { calcitonin concentrations }\end{array}$ & $\begin{array}{r}8 \\
9 \\
10 \\
11 \\
12 \\
13 \\
14\end{array}$ & $\begin{array}{l}0 \\
0.3 \\
0.6 \\
1.2 \\
2.4 \\
4.8 \\
9.6\end{array}$ & \\
\hline $\begin{array}{l}\text { Serum from patient } \mathbf{B} . \text { F. with } \\
\text { medullary thyroid carcinoma } \\
\text { diluted in pooled, normal serum } \\
\qquad\end{array}$ & $\begin{array}{l}15 \\
16 \\
17 \\
18 \\
19\end{array}$ & & $\begin{array}{l}1: 64 \\
1: 32 \\
1: 16 \\
1: 8 \\
1: 4\end{array}$ \\
\hline $\begin{array}{l}\text { Serum pooled from four patients } \\
\text { with medullary thyroid carcinoma }\end{array}$ & 20 & & \\
\hline $\begin{array}{l}\text { Serum of a thyreoidectomized } \\
\text { patient }\end{array}$ & 21 & & \\
\hline
\end{tabular}

Tab. 2. Radioimmunoassay conditions.

\begin{tabular}{|c|c|c|c|c|c|c|c|c|}
\hline $\begin{array}{l}\text { Lab. } \\
\text { code }\end{array}$ & Antibody & $\left.\operatorname{Tracer}^{\mathbf{X}}\right)$ & $\begin{array}{l}\text { Specific } \\
\text { activity } \\
(\mathrm{MBq} / \mu \mathrm{g})\end{array}$ & $\begin{array}{l}\text { Human } \\
\text { calcitonin } \\
\text { (sequence } \\
1-32 \text { ) } \\
\text { standard } \\
\text { from }\end{array}$ & $\begin{array}{l}\text { Incubatior } \\
\text { withoüt } \\
\text { tracer } \\
\text { (days) }\end{array}$ & $\begin{array}{l}\text { n time } \\
\text { with } \\
\text { tracer } \\
\text { (days) }\end{array}$ & Separation & $\begin{array}{l}\text { Reference } \\
\text { range } \\
(\mu \mathrm{g} / 1)\end{array}$ \\
\hline 1 & chicken, $15-25$ & {$\left[{ }^{125} \mathrm{I}\right] \mathrm{hCT}$} & 3.7 & Armour & 3 & +3 & dextran chạcoạl & $0.1-0.43$ \\
\hline 2 & goat, 3. 3. 77 & $?$ & 3.9 & Ciba & 2 & +2 & dextran charcoal & $0.1-0.3$ \\
\hline 3 & goat, 3. 3. 77 & {$\left[{ }^{125} \mathrm{I}\right] \mathrm{hCT}$} & [ 4.7 & Cịba & $18 / 24$ & $+15 / 24$ & $\begin{array}{l}\text { polyethyleneglycol } \\
120 \mathrm{ml} / \mathrm{l}\end{array}$ & $0.1-1.0$ \\
\hline 4 & goat, 3. 3. 77 & {$\left[{ }^{125} \mathrm{I}\right] \mathrm{hCT}$} & I ? & Ciba & 2 & +2 & dextran charcoal & 0.05 \\
\hline 5 & $\begin{array}{r}\text { goat, } 3.3 .77 \\
\text { 8. } 11.75\end{array}$ & {$\left[{ }^{125} \mathrm{I}\right] \mathrm{hCT}$} & T 4.0 & Ciba & 2 & +1 & dextran charcoal & $0.1-0.5$ \\
\hline 6 & $\begin{array}{l}\text { goat, } 18.1 .78 \\
\text { goat, 6A, day } 143 \\
\text { (Fischer) }\end{array}$ & $?$ & 5.5 & Ciba & 3 & +3 & dextrạn charcoal & $\begin{array}{ll}? & -0.3\end{array}$ \\
\hline 7 & goat, 8. 11. 75 & $\left.{ }_{\mathrm{hCT}}^{125} \mathrm{I}\right]-$ & 4.7 & Ciba & 3 & +3 & dextran charcoal & $0.06-0.41$ \\
\hline 8 & $\begin{array}{l}\text { goat, } 6 \mathrm{~A} \text { day } 143 \\
\text { (Fischer) }\end{array}$ & $\left.{ }_{\mathrm{hCT}}^{125} \mathrm{I}\right]-$ & 2.6 & Ciba & 2 & +3 & charcoal & $0.06-0.3$ \\
\hline 9 & goat, 3. 3.77 & ? & $?$ & Ciba & 2 & +2 & $\begin{array}{l}\text { polyethỳleneglycol } \\
150 \mathrm{ml} / 1\end{array}$ & $0.07-0.45$ \\
\hline 10 & $\begin{array}{l}\text { goat, 6A, day } 143 \\
\text { (Fischer) }\end{array}$ & {$\left[{ }^{125} \mathrm{I}\right] \mathrm{hCT}$} & {$[11.1$} & Ciba & 2 & +3 & dextran charcoal & $0: 01-0.05$ \\
\hline 11 & rabbit, $\mathrm{H} 31$ & $?$ & 16.7 & Ciba & 2 & +2 & dextran charcoal & $0.11-0.36$ \\
\hline 12 . & $\begin{array}{l}\text { guinea pig } \\
9654, \text { goat, g-5 } \\
\text { 8.11.76,3.3.77 }\end{array}$ & $?$ & 9.8 & Organon & 5 & +3 & dextran charcoal & $0.02=0.12$ \\
\hline
\end{tabular}

x) $\mathrm{hCT}=$ human calcitonin
Tab. 1. Composition of the 21 test sera.

Serum from patient $\vec{B}$.F. with medullary thyroid carcinoma

Serum pooled from four patients 20

Serum of a thyreoidectomized 21

patient 
1:64 should have had a concentration near the upper limit of the reference range, and the serum of the thyreoidectomized patient was practically calcitonin free. In the 12 laboratories the upper limit of the normal range varied between 0.05 and $1.0 \mu \mathrm{g} / \mathrm{l}$, but was close to $0.5 \mu \mathrm{g} / 1$ in most. The detection limit, which defines the lower limit of the reference range, was between 0.01 and $0.11 \mu \mathrm{g} / 1$, but predominately around $0.1 \mu \mathrm{g} / 1$. Eight laboratories detected no calcitonin in the serum of the thyroidectomized patient, while the values measured in the other laboratories were within the reference range. Nine laboratories recognized the serum of the medullary thyroid carcinoma patient diluted 1:64 as a pathological value slightly above the normal range.

\section{Conclusion}

The participating laboratories in the comparative study of the calcitonin determination were able to distinguish between different concentrations of calcitonin, in serum or buffer although the absolute values were scattered over a wide range. Possible causes for these differences include the known immunoheterogeneity of circulating calcitonin (12), different reagents used as a standard, tracer and antibodies and different times and temperatures used for the incubation, and lastly different separation techniques. Although participants used homologous radioimmunoassay systems and only one laboratory encountered technical problems with the radioimmunoassay, the wide scatter of individual values determined for one given concentration meant that absolute values could not be used for comparison of immunoassay results. A reasonable agreement was reached however, when the data were calculated as a factor of a given value. We conclude that a standard with a defined calcitonin concentration should be used by all laboratories as an internal standard in every assay. This standard should be diluted in pooled serum as well as
Tab. 3. Means and coefficients of variations (CV) of the calcitonin concentrations measured in the serum from patient B.F. with medullary thyroid carcinoma (mean $\overline{\bar{x}}) \pm$ SD of undiluted serum of the patient with medullary thyroid carcinoma values as calculated for each laboratory from the dilution curves, $\mathrm{CV} \%=$ coefficient of variation for each laboratory).

\begin{tabular}{lllll}
\hline $\begin{array}{l}\text { Lab. } \\
\text { code }\end{array}$ & $\begin{array}{l}\text { Calcitonin } \\
\text { x }\end{array}$ & $\begin{array}{l}\text { SD } \\
(\mu \mathrm{g} / 1)\end{array}$ & $\mathrm{n}$ & $\begin{array}{l}\text { CV } \\
(\%)\end{array}$ \\
\hline & $(\mu \mathrm{g})$ & & 4 & 46.0 \\
1 & 106.6 & 62.7 & 4 & 23.7 \\
2 & 62.7 & 14.9 & 5 & 24.0 \\
3 & 52.4 & 12.6 & 5 & - \\
4 & - & - & 1 & 24.4 \\
5 & 59.8 & 14.6 & 5 & 46.8 \\
6 & 165.8 & 77.6 & 3 & 69.3 \\
7 & 18.9 & 13.1 & 5 & 36.0 \\
8 & 27.0 & 16.8 & 5 & 11.5 \\
9 & 63.4 & 10.4 & 5 & 36.5 \\
10 & 40.8 & 4.8 & 5 & 22.2 \\
11 & 50.4 & 18.4 & 5 & 5 \\
12 & 16.2 & 3.6 & 5 &
\end{tabular}

consensus value (mean of all laboratories excluding lab. No. $4,6,12$.

$$
\begin{array}{ll}
\overline{\mathrm{x}} & =53.5 \mu \mathrm{g} / 1 \\
\mathrm{SD} & =25.1 \mu \mathrm{g} / 1 \\
\mathrm{n} & =.9-^{-} \\
\mathrm{CV} \% & =46.9
\end{array}
$$

in buffer. We suggest that this standard might be the international reference preparation for calcitonin of the National Institute for Biological Standards and Control, which has been recently tested in a comparative study of in vitro bioassays (13). Since this comparative study focussed on pathologically elevated levels, the reference range was not defined. For clinical purposes it is most important however to differentiate between nörmal and slightly elevated calcitonin concentrations, for example in order to detect patients with medullary thyroid carcinoma. Therefore subsequent comparative studies are necessary to define the reference range.

\section{References}

1. Deftos, L. J. (1978) Adv. Int. Med. 23, 159-193.

2. Coombes, R. C., Hillyard, C. J., Greenberg, P. G. \& MacIntyre, I. (1974) Lancet $I, 1080-1083$.

3. Tashjian, A. H., Howland, B. C., Melvin, K. E. W. \& Hill, C. S. (1971) New. Ėng. J. Med. 283, 890-895.

4. Deftós, L. J. (1971) Metabolism 20, 1122-1128.

5. Silva, O. L., Snider, W. H. \& Becker, K. (1974) Clin. Chem. 20, 337-339.

6. European PTH Study Group (EPSG) (1978) Europ. J. Clin. Invest 8, 149-154.

7. Marschner, J., Bottermann, P., Erhardt, F., Linke, R., Löffler, G., Maier, V., Schwandt, P., Vogt, W. \& Scriba, P. C. (1974) Horm. Metab. Res. 6, 293-296.

8. Horn, K., Marschner, J. \& Scriba, P. C. (1976) J. Clin. Chem. Clin. Biochem. 14, 353-360.

9. Wood, W. G., Bauer, M., Horn, K., Marschner, J., van Thiel, D., Wachter, C. \& Scriba, P. C. (1980) J. Clin. Chem. Clin. Biochem. 18, 511-519.

10. Hunter, W. M. \& Greenwood, F. C. (1962) Nature (London) 194, 495-496.

11. Tashjian, A. H., Jr. (1969) Endocrinology 84, 140-148.

12. Singer, F. R. \& Habener, J. F. (1974) Biochem. Biophys. Res. Commun. 61, 710-713.

13. Gaines Das, R. E. \& Zanelli, J. M. (1980) Acta Endocrinol. $93,37-42$.

Dr. F. Raue

Abt. Endokrinologie Med. Poliklinik

Universität Heidelberg

Luisenstr. 5

D-6900 Heidelberg 
